\title{
A teoria da firma: crítica à visão neoclássica e enfoque heterodoxo*
}

\section{Theory of the firm: critique to neoclassical theory and heterodox approach}

\author{
Achyles Barcelos da Costa $\star \star$
}

\begin{abstract}
Resumo: Este texto discute a teoria econômica da firma por meio de desenvolvimentos analíticos dedicados a esse objeto de investigação, denominados neoclássicos e heterodoxos. O objetivo é difundir o debate sobre essa instituição alargando, assim, o leque conceitual à disposição dos estudantes de Economia no estudo do desenvolvimento econômico. Para isso, apresenta-se a firma em perspectiva histórica, discutem-se as principais correntes do enfoque neoclássico e suas limitações, finalizando com a contribuição da visão heterodoxa.
\end{abstract}

Palavras-chave: Teoria da firma.Visão neoclássica. Heterodoxia.

\begin{abstract}
This paper discusses the economic theory of the firm through the analytical developments that have been devoted to this research object, called neoclassical and heterodox. The purpose is to diffuse the treatment of this institution beyond that provided by the mainstream neoclassical.Thus, it is aimed to broadening the conceptual range available to the students of economics in the study of economic development. To achieve this goal, the paper focuses the firm in historical perspective, discusses the main currents of the neoclassical approach and its limitations and ends with the contribution of heterodox vision.
\end{abstract}

Keywords: Theory of the firm. Neoclassical. Heterodoxy.

JEL: B5; D2; L2

\footnotetext{
* Submissão: 21/11/2019 | Aprovação: 09/02/2021 | DOI: 10.29182/hehe.v24i2.703

$\star \star$ Professor titular aposentado da Universidade Federal do Rio Grande do Sul (UFRGS) | E-mail: achyles. bc@ufrgs.br | ORCID: 0000-0003-1528-8679
} 


\section{Introdução}

A firma ${ }^{1}$ é uma instituição central na economia capitalista. É ela que, de um modo geral, comanda os recursos produtivos, produzindo para o mercado os bens e serviços que a sociedade irá consumir. Nesse modo de organização social, em que a propriedade dos meios de produção é privada e as decisões do que, como e para quem produzir são tomadas de maneira descentralizada, há disputa entre capitalistas e trabalhadores pelo excedente; e entre capitais na sua realização no mercado.

Nesse movimento, a inovação em seus diferentes tipos - seja tecnológica, seja organizacional - desempenha papel fundamental na busca de lucratividade pela redução de custos e diferenciação de produtos, de modo a fortalecer a competitividade empresarial. As empresas estão incessantemente pesquisando novidades e estabelecendo estratégias com vistas a se diferenciarem de suas concorrentes - em preço ou em algum atributo da mercadoria produzida - de forma a serem bem-sucedidas nessa batalha, a qual se renova diariamente. É a essa procura por inovação que Marx e Engels ([1848] 2010, p. 43) se referiam no Manifesto Comunista ao postularem que: "A burguesia não pode existir sem revolucionar incessantemente os instrumentos de produção [...]."; Schumpeter ([1942] 1984, p. 112-113), por sua vez, a via como sendo determinante no desenvolvimento econômico capitalista, e que chamou de "destruição criativa".

Embora a inovação tenha um caráter ubíquo em suas origens, não há dúvidas de que a empresa é uma das principais fontes de conhecimento, sendo ela quem basicamente o materializa em novas tecnologias, introduzindo as novidades no sistema econômico, sendo algo intrínseco ao processo de concorrência de mercado. Dado esse papel central que a firma desempenha na dinâmica do capitalismo, uma teoria do desenvolvimento econômico requer uma fundamentação teórica que dê conta desse ente institucional. Entender a sua natureza, saber as mudanças pelas quais têm passado em seu evoluir, conhecer os seus limites em relação ao mercado, ou como ela coevolui com este último, é um requisito importante para compreender as transformações econômicas, sociais e políticas da sociedade ao longo do tempo. Para isso, é necessário incorporar a História Econômica na análise, de modo a integrar História e Economia (Lazonick, 1991, 2003). Como já argumentara Schumpeter ([1954] 1964, p. 35):

\footnotetext{
${ }^{1}$ Firma e empresa serão termos utilizados de maneira intercambiável neste texto.
} 
Ninguém poderá entender o complexo econômico de qualquer época, a presente inclusive, se não possuir uma visão adequada dos fatos históricos e senso histórico bastante, ou algo que pode ser classificado como experiência_histórica.

Contudo, o debate sobre a firma na literatura econômica é limitado. No âmbito da corrente neoclássica de pensamento econômico, que domina a discussão teórica e o ensino de economia, o estudo sobre a firma - na visão mais ortodoxa ou convencional - mostra-se bastante restrito. Nessa ótica, a empresa é um ente passivo e a-histórico, tratado como outro agente qualquer, que busca maximizar a sua função-utilidade sujeita a determinadas restrições. Em outras variantes do neoclassicismo, por exemplo, como na teoria dos custos de transação, ela é considerada como uma solução para eventuais falhas de mercado, ao qual, de um modo geral, é dado o protagonismo principal.

O objetivo do presente texto é chamar a atenção para a necessidade de uma teoria da firma na compreensão do processo de desenvolvimento econômico. $\mathrm{O}$ esforço de sistematização da literatura busca romper a limitada discussão da teoria neoclássica ortodoxa e suas variantes, difundindo abordagens que veem a firma como uma instituição dinâmica e histórica. Isso não se deve apenas a uma pretensão didática ou democrática, dado que, por óbvio, aqueles que se dedicam ao estudo da ciência econômica devem estar a par das diferentes visões existentes sobre a dinâmica do mundo econômico. Mais do que isso: distintas explicações da realidade implicam diferentes prescrições sobre como atuar sobre ela. As interpretações do mundo econômico que podem ser objetivas, mas que não são neutras, carregam consigo ideologias explícitas ou implícitas, conscientes ou inconscientes. Não por outra razão essa disciplina do conhecimento é também chamada de Economia Política.

O texto, além desta introdução, contém mais quatro seções. A primeira procura resgatar a natureza histórica dessa instituição capitalista, chamada firma. A ideia geral não é detalhar as diferentes transformações por que passou essa instituição ao longo do tempo, mas mostrar que ela é produto e um agente da história, e, nesse sentido, uma teoria da firma deveria contemplar essa dimensão. A segunda seção inicia a discussão teórica propriamente dita, identificando as principais versões da visão mainstream ou neoclássica da firma e apontando suas principais limitações. Apresenta-se inicialmente a abordagem convencional, que domina os livros-texto de economia, que vê a firma como uma função de produção. Esse enfoque os críticos às vezes chamam de visão da firma como uma black box. Ainda nessa seção são expostas 
as variantes neoclássicas mais "realistas" da firma, baseadas em relações de contratos, como a teoria dos custos de transação e a teoria do nexo de contratos ou de agência, mas que ainda se subordinam ao individualismo metodológico e à otimização condicionada, empregados pela visão convencional. A terceira seção introduz os desenvolvimentos teóricos que poderiam ser chamados genericamente de "heterodoxos" (em oposição à ortodoxia neoclássica), dado que não há uma hegemonia estabelecida de um enfoque particular. O vocábulo "heterodoxia" ou "heterodoxo" tem um conteúdo amplo e não inclui apenas aqueles autores que tratam da teoria da firma e que pertencem a essa linha de pensamento econômico. Lee (2008) menciona que existem um conjunto de correntes consideradas heterodoxas incluindo, por exemplo, a teoria pós-keynesiana, a economia marxista, entre outras. O que diferencia essas correntes encontra-se nos conceitos que empregam e no objeto de análise específico de sua agenda de pesquisa. De um modo geral, o que distingue a perspectiva heterodoxa da teoria da firma em relação à neoclássica é a sua análise dinâmica e histórica dos fenômenos econômicos. A quarta e última seção faz uma síntese e avaliação final do que foi discutido nas seções anteriores.

\section{A firma em perspectiva histórica}

A atividade produtiva para a venda de bens e serviços no mercado é antiga e anterior ao capitalismo. Rosenberg e Birdzell Jr. (1986, p. 159) relatam a existência de empreendimentos privados com centenas de trabalhadores na produção, por exemplo, de navios e produtos do ferro, muito antes do período em que se inicia a Revolução Industrial. ${ }^{2}$ Mas essas configurações eram iniciativas raras na paisagem econômica. A produção de riqueza material da sociedade estava limitada, à época, à atividade agrícola exercida nas terras de nobres ou de senhores feudais.

No âmbito do estudo de Economia, a independência dessa disciplina enquanto um corpo particular de conhecimento começa a se desenvolver de maneira mais sistemática, a partir do século XV, com os estudos do que se convencionou chamar em história do pensamento econômico de "escola mercantilista". A produção de conhecimento econômico dessa corrente in-

\footnotetext{
2 Não há consenso entre os historiadores (Henderson, [1969] 1979; Cazadero, 1995) sobre um período específico no qual teria ocorrido a I Revolução Industrial, mas, grosso modo, pode-se afirmar que o seu início ocorre a partir da segunda metade do século XVIII.
} 
forma que a riqueza de uma nação está associada à posse de metais preciosos, adquiridos mediante a formação de superávits comerciais entre países. Já para a escola fisiocrata, que se segue à mercantilista, a atividade agrícola era aquela considerada produtiva, sendo a única capaz de gerar excedentes na economia. Os autores dessa corrente diferiam de seus antecessores ao deslocarem a formação da riqueza do âmbito das trocas para a esfera da produção. ${ }^{3}$ Mas em ambas as escolas não há uma preocupação com algo que seja parecido com "a firma" ou empresa, enquanto categoria analítica particular. As transformações da sociedade ainda não tinham alcançado um nível de desenvolvimento de suas forças produtivas em que a firma se destacasse como uma instituição independente e com papel central no processo de crescimento econômico. Isso só vai ocorrer a partir da I Revolução Industrial.

Até o advento da I Revolução Industrial, a partir da segunda metade do século XVIII, a atividade manufatureira tinha características artesanais, sendo realizada no próprio lugar de moradia de artesãos, seja no campo seja na cidade. No caso daquelas atividades que necessitavam de alguma fonte de energia natural, a sua execução ficava subordinada à existência de fontes como rios e quedas d'água. A divisão social do trabalho era ainda relativamente pouco desenvolvida, pois o grosso da riqueza nacional estava concentrado na agricultura. Mas, já então, a ideia de uma maior eficiência produtiva pela divisão do trabalho começa a se manifestar. Adam Smith (1723-1790) é testemunha ocular das transformações em curso. Em sua obra $A$ riqueza das nações (Smith, [1776] 1958), o autor salienta os benefícios da divisão do trabalho fabril para o aumento da produtividade e da riqueza de um país. Mas embora Smith faça menção à divisão do trabalho na fabricação de alfinetes em uma pequena fábrica por ele visitada, o tratamento que dá ao trabalho é em sentido geral: na laboriosidade e na destreza dos trabalhadores enquanto profissionais associados a uma determinada atividade ou ofício. Eles são tratados como o tecelão, o tintureiro, o ferreiro etc., e não como uma atividade exercida por uma instituição organizacional chamada empresa que contrata esses operários, fazendo sua organização e controle para realizar a produção de mercadorias com lucro. A preocupação de Smith é com os efeitos mais gerais da combinação de capital e de trabalho na produção da riqueza.

\footnotetext{
${ }^{3}$ Sobre o conceito de riqueza da escola mercantilista e a crítica de Smith a essa corrente de pensamento, ver Smith ([1776] 1958), capítulo 1 do livro quarto). A escola mercantilista e a fisiocrata também podem ser encontradas em livros de história do pensamento econômico como, por exemplo, o de Brue ([2000] 2005), capítulos 2 e 3.
} 
Embora não se possa estabelecer que a empresa seja fruto da Revolução Industrial, a sua importância e sua difusão na estrutura produtiva da sociedade vão se firmar a partir das transformações tecnológicas por ela engendradas. Nas palavras de Rosenberg e Birdzell Jr. (1986, p. 159): “Mas se não podemos afirmar que a fábrica foi uma invenção da Revolução Industrial, podemos dizer que poucos ocidentais conheciam uma delas antes de 1750 , e que poucos podiam deixar de vê-las por volta de 1880".

A passagem do artesanato para a manufatura, ou para o sistema fabril, ocorre com a mudança nos métodos de produção propiciada pelo emprego da tecnologia e das matérias-primas associadas à Revolução Industrial (a máquina a vapor, o tear mecânico, o ferro e o aço). Até então, a atividade produtiva era feita por empreitada, realizada pelo artesão em sua própria moradia, o chamado putting out system, com o auxílio de alguns aprendizes, que com ele também podiam conviver na mesma residência. As encomendas dos produtos aos artesãos tinham origem nos comerciantes que avançavam a esses produtores as matérias-primas e os insumos necessários para a confecção dos produtos, que, depois de prontos, eram destinados aos mercados locais e externos. Nessa forma de organização da produção, o artesão ou o mestre do oficio tinham o pleno controle do seu tempo de trabalho e dos procedimentos que se empregavam sobre a matéria-prima para obter o produto final. Com o advento da maquinaria pesada, a partir do motor a vapor, essa realidade produtiva vai perdendo vitalidade, dando espaço a um novo tipo de arranjo organizacional: a fábrica como firma de capital privado.

Mas a tese de que a passagem da casa para a fábrica, ou da residência do produtor para um local independente e externo àquele lugar, com uma organização do trabalho especializada e hierárquica, em vez de horizontal, se devesse a uma questão tecnológica e de eficiência, como preconizada por Smith ([1776] 1979), por Rosenberg e Birdzell Jr. (1986) e outros autores, não é isenta de contestações. Uma das mais reconhecidas é a objeção feita por Stephen Marglin, em seu artigo de 1974:" What do bosses do? The origins and functions of hierarchy in capitalist production". Nele Marglin coloca sob a forma de questionamento se é a tecnologia que determina a organização econômica e social ou, ao contrário, se esta última é quem define a tecnologia (Marglin. [1974] 1994). Para Marglin, a fábrica intermediando o trabalhador e o produto de seu trabalho é um instrumento capitalista, iniciativa do proprietário do capital com o intuito de controlar o processo de trabalho e justificando, assim, a sua existência como agente econômico. De acordo com esse 
autor, a divisão do trabalho, como retratada por Adam Smith na produção de alfinetes, em que cada trabalhador se especializa em fases distintas da produção, não decorre de uma necessidade tecnológica. $\mathrm{O}$ mesmo resultado produtivo poderia ser alcançado, por exemplo, com um trabalhador e sua família executando em conjunto cada uma das tarefas, em vez de cada um se especializar por separado em uma delas.

$\mathrm{Na}$ realidade, a fábrica pode atender a ambos os objetivos: o controle do processo de trabalho e a busca por maior eficiência. Dada a dimensão que a produção em escala alcançou, dificilmente a moradia do artesão comportaria teares movidos a vapor. Segundo Rosenberg e Birdzell Jr. (1986, p. 163):

O motor a vapor não só contribuiu para levar a produção da cabana para as fábricas, mas também para mudar a localização destas últimas. $\mathrm{O}$ motor a vapor não era um dispositivo que pudesse ser instalado em choupanas ou em oficinas familiares urbanas. Precisava de instalação especializada, preferivelmente perto de uma fonte de carvão.

A fábrica, ou a empresa, como um local independente, onde a manufatura era realizada sob uma coordenação hierárquica, tornou-se uma instituição que rapidamente difundiu-se na estrutura produtiva. Chandler ([1959] 1998) e outros estudiosos de história empresarial informam algumas características que essa instituição assumiu desde o seu surgimento. $O$ perfil de empresa que se firmara na atividade econômica, e que dominou a atividade industrial até por volta do último quarto do século XIX, caracterizava-se por ser de porte relativamente pequeno, atuando em um horizonte geográfico local, tanto no que se refere ao mercado de produto final quanto à compra de matérias-primas. Essas empresas não possuíam canais próprios de distribuição, e a venda de seus produtos ocorria por meio de intermediários. Argumento semelhante é feito por estudiosos da firma enquanto organização, como Milgrom e Roberts (1992, p. 539, tradução nossa):

Antes de 1850 não existiam estruturas hierárquicas, a não ser na Igreja e no Exército. [...] A manufatura era conduzida, de um modo geral, em pequena escala. Uma pessoa, ou um pequeno grupo de pessoas, contratava os empregados e dirigia todas as atividades do negócio, e cada empreendimento era limitado, então, a uma escala que o empresário pudesse pessoalmente supervisionar. O pequeno porte de empresa atendia geralmente os tipos de mercado de então [...] a maioria desses mercados era local e as empresas adaptavam-se a esse padrão. 
Ao final do século XIX, essa empresa de pequeno porte muda em dimensão, passando, em decorrência, por uma transformação qualitativa. $\mathrm{O}$ emprego do vapor nos transportes hídricos e a introdução do modal ferroviário, em que se ampliavam territorialmente o deslocamento de pessoas e mercadorias, levaram à constituição de grandes empresas burocratizadas, não só nesses segmentos da atividade produtiva, mas também naqueles destinados aos bens de consumo e de produção, particularmente na indústria americana. Chandler ([1959] 1998) relata que a complexidade da atividade ferroviária com sua escala e volume de mão de obra empregada estabeleceu um tipo de empresa que apresentava uma estrutura organizacional interna departamentalizada, de gestão profissional, além de instituir novas formas de concorrência nos mercados: a oligopolista.A expansão da ocupação do território americano, os desenvolvimentos dos meios de transportes e de comunicação - com o uso do telégrafo, do cabo submarino -, a independência da fábrica de sua localização próxima a fontes naturais de energia, os novos avanços tecnológicos com a eletricidade e o motor de combustão interna, entre outros, permitiram a formação de mercados de massa e de aglomerados urbanos. As empresas que inicialmente aproveitaram essas novas oportunidades de crescimento foram aquelas vinculadas à produção de bens de consumo. Constituíram-se grandes empresas por meio da integração vertical na produção de matérias-primas e na distribuição dos produtos, bem como por associações e fusões de pequenas empresas, formando grandes empreendimentos. A esses setores seguiram-se aqueles vinculados aos bens de produção. Conforme Chandler ([1959] 1998, p. 61):

A grande empresa moderna, executora dos principais processos industriais, a saber, a aquisição e geralmente a produção de matérias-primas e componentes, a manufatura, a comercialização e as finanças - tudo isso numa mesma estrutura organizacional - tem origem nessa época. À exceção das ferrovias, tais organizações praticamente não existiam antes da década de 1880. Por volta de 1900, elas haviam-se tornado a unidade empresarial básica da indústria norte-americana.

O resultado desse movimento é que a coordenação da atividade econômica pelas forças impessoais do mercado - a chamada "mão invisível", de Adam Smith - é alterada pela visible hand dos administradores da grande empresa, como Chandler (1977) vai intitular a sua obra em que discute esse movimento (Chandler, 1977). ${ }^{4} \mathrm{O}$ financiamento desses grandes empreendimentos

\footnotetext{
${ }^{4}$ Esses motivos que deram surgimento à grande empresa receberam contestações. Ao contrário de Chandler,
} 
já não podia depender apenas de pequenas poupanças pessoais de seus proprietários. Os investimentos em capital fisico para viabilizar os negócios requeriam vultosos recursos financeiros. Essa é a origem, segundo Chandler ([1967] 1998), de Wall Street e seus bancos de investimento.

Dado que os recursos envolvidos nesses empreendimentos eram de monta significativa, os riscos de perdas por negócios malsucedidos também se tornavam elevados. A busca por uma organização que permitisse juntar recursos e que também limitasse as responsabilidades individuais, minimizando os riscos de prejuízos, já vinha sendo tentada há muito tempo, principalmente na Europa. No geral, a existência de grandes empreendimentos administrados por particulares para exercer atividade econômica restringia-se às concessões públicas e às cartas-patente outorgadas pelos soberanos, como nos casos das Companhias das Índias Ocidentais e Orientais, em que o concessionário tinha também o direito exclusivo de exploração. Até fins do século XIX era muito difícil constituir negócios de maneira autônoma por grupos de indivíduos, em que se pudesse negociar no mercado sua participação acionária. Isso vai ser possível apenas a partir da década de 1890, particularmente com a experiência americana, quando ocorre a formação de mercado de ações industriais. Mas o surgimento da sociedade anônima, em que pese o seu sucesso, não foi a única forma de organização empresarial a exercer a atividade em grande escala. Coexistiam com ela outros tipos mais tradicionais, por exemplo, os de um único ou de dois ou três proprietários individuais (Rosenberg; Birdzell Jr., 1986).

Contudo, a maneira como essa instituição chamada firma se incorporou ao debate teórico entre economistas tem variado ao longo do tempo ao sabor de diferenças ideológicas e de marcos teórico-analíticos seguidos. ${ }^{5}$ É o que será visto nas seções 2 e 3 a seguir.

\footnotetext{
para quem ela resulta de estratégia empresarial, Williamson (1981) considera que se deveu à criação organizacional na busca por redução nos custos de transação. Isso também, segundo ele, explicaria o aparecimento da firma conglomerada e da multinacional. Para uma discussão da teoria dos custos de transação, ver a seção 2 a seguir. A passagem da grande empresa de administração unitária para uma multidivisional é discutida em Chandler ([1960] 1998).

${ }^{5}$ Tigre (1998) levanta a interessante hipótese de que as diferenças teóricas existentes se devem não só ao fato de que há distintos tipos de firmas, mas que o instrumental conceitual utilizado no mais das vezes é desenvolvido em contextos socioeconômicos que não mais prevalecem, havendo, portanto, um gap temporal entre o modelo teórico e a realidade a qual pretende explicar.
} 


\section{A teoria neoclássica da firma: a ortodoxia e suas variantes}

No capítulo introdutório de sua obra An evolutionary theory of economic change, Nelson e Winter ([1982] 2005) chamam a atenção para as dificuldades em identificar o que seria o enfoque “ortodoxo", pois o mesmo se apresenta com nuances analíticas. Contudo, não seria despropositado observá-lo, segundo ainda os autores, como sendo aquele que é apresentado nos livros-texto de microeconomia, seja em âmbito do ensino de graduação ou de pós-graduação. Este último nível de ensino difere do primeiro basicamente pela sua formulação matemática mais sofisticada. A característica geral definidora do enfoque neoclássico de teoria econômica é a sua análise estática e de equilíbrio. Esse caminho metodológico implica desconsiderar o processo histórico de formação das instituições econômicas da sociedade, bem como as relações sociais estabelecidas em seu interior. Não é surpresa, então, que a teoria neoclássica em seu viés mais ortodoxo não se preocupe em explicar a origem das instituições - a empresa incluída - e as suas transformações históricas. No enfoque neoclássico, a firma ora aparece como uma organização passiva, sem uma história e conteúdo interno informando o seu desenvolvimento, cumprindo apenas uma função subsidiária em um mecanismo maior (o mercado) -, ora como um complemento a este último. De um modo geral, ao mercado, na sua perfeição, é dado o protagonismo principal na coordenação da atividade econômica.

O enfoque neoclássico ortodoxo padrão é aquele que trata a firma apenas como uma função de produção, em que se combinam capital e mão de obra - os chamados fatores de produção - para gerar determinado volume de produto. As quantidades de fatores empregadas e de produto gerado irão depender, para uma dada técnica, de seus preços relativos de mercado. A combinação resultante de insumos e o volume de produto produzido devem ser tais que maximizem o lucro da firma. No alcance desse objetivo não se atribui à firma um papel ativo. Segundo Lee (1990), nessa visão o foco da análise não é a firma, mas o ambiente em que ela atua. A firma simplesmente se adapta às condições de mercado. Nessa situação, não há lugar para o empresário ou para alguém que tome decisões de estratégicas competitivas, nem há uma estrutura organizacional para viabilizar a trajetória competitiva escolhida. ${ }^{6}$ É apenas uma questão de eficiência tecnológica.

\footnotetext{
${ }^{6}$ A discussão de estratégica nesse enfoque ortodoxo é no sentido do estabelecimento de preço e produção nos casos de estruturas de mercado oligopólicas, em que se supõe a existência de interdependência em-
} 
Apenas para ilustrar, em um dos livros festejados de microeconomia (Varian, [1996] 1999), inclusive utilizado no ensino de pós-graduação, não há entre os seus 35 capítulos e 740 páginas, da edição em português, um único capítulo sequer dedicado exclusivamente à teoria da firma, no sentido de discutir o surgimento dessa instituição e os seus limites, bem como os diferentes enfoques a seu respeito. A palavra "empresa" aparece dispersa ao longo do livro, mas sem uma abordagem teórica particular. O tema da firma é tratado ali como o "produtor", a contrapartida do "consumidor". A firma é, nessa abordagem neoclássica convencional, uma black box, sem conteúdo organizacional interno e formas institucionais assumidas. De maneira simplificada, podemos dizer que toda a discussão no enfoque neoclássico padrão se resume em cruzar a oferta, ao lançar mão da firma como uma função de produção, com a demanda, para chegar ao preço de equilíbrio de mercado. Nesse modelo analítico de livro-texto, a teoria do consumidor é desenvolvida para obter a curva de demanda negativamente inclinada (a partir da lei da utilidade marginal decrescente, ou dos efeitos renda e substituição com o emprego das curvas de indiferença). Já a teoria da empresa ou do produtor é para chegar à curva de oferta positivamente inclinada (com base na lei dos rendimentos decrescentes). Do cruzamento de ambas as curvas - de demanda e de oferta - obtêm-se o preço e a produção de equilíbrio de mercado. ${ }^{7}$ Tanto de um lado (consumidor) quanto do outro (produtor), nenhum deles tem poder individualmente para influir no preço final das mercadorias. ${ }^{8} \mathrm{~A}$ ideia, ao fim e ao cabo, é que os preços fixados dessa maneira impessoal pelo mercado estariam representando os desejos dos "indivíduos" (produtores, consumidores ou famílias) e nesse sentido eles seriam os "preços corretos" estabelecidos na economia.

O máximo de espaço específico destinado à qualificação da empresa no livro de Varian é o subitem 18.2, "A organização das empresas", com pouco mais de meia página do capítulo 18, intitulado "Maximização do lucro", em que faz uma breve caracterização dessa instituição.

\footnotetext{
presarial. No geral, a análise é feita recorrendo ao emprego da teoria dos jogos com vistas à maximização dos lucros.

${ }^{7}$ Já em 1926, Sraffa ([1926] 1988) fez uma crítica a esse modelo de oferta e de demanda marshalliano na explicação dos preços das mercadorias, mostrando as suas inconsistências, como se verá mais adiante neste texto.

${ }^{8}$ Os casos em que a influência seja possível - mercados de monopólio ou de oligopólio - são tratados como "imperfeições" ou "falhas" que merecem ser corrigidas ou reguladas por meio da ação do Estado. O modelo canônico, utilizado como base normativa e benchmark para o bem-estar social, é o da concorrência perfeita.
} 
Numa economia capitalista, as empresas são de propriedade de indivíduos. As empresas são apenas entidades legais, em última instância os donos das empresas são responsáveis pelo seu comportamento e são os donos que recebem os prêmios ou pagam os custos desse comportamento. (Varian, [1996] 1999, p. 343-344)

A microeconomia neoclássica trata todos como sendo iguais:indivíduos. Não há discussão alguma sobre por que alguns indivíduos são "donos" ou proprietários de empresas e outros não. Classes e relações sociais não fazem parte da análise. As firmas são “apenas" entes jurídicos. Tanto faz se a empresa é individual, como um microempresário que emprega dois ou três trabalhadores ou uma montadora multinacional de veículos automotores, com milhares de trabalhadores e subsidiárias em distintos países: ambas, de acordo com a teoria, comportam-se de maneira semelhante, buscam a maximização do lucro, condicionadas pela tecnologia e pelo mercado. ${ }^{9}$ São tratadas como espécimes de um mesmo gênero. $\mathrm{O}$ livro prossegue ainda no reconhecimento de que mais de um "indivíduo" possa ser proprietário de uma mesma empresa, como no caso das sociedades anônimas, com a particularidade de que nesse caso a sociedade pode durar mais do que a vida de seus donos. E com certo simplismo estabelece: "Por essa razão, a maioria das grandes empresas é organizada como sociedades anônimas" (Varian, [1996] 1999, p. 344). Admite-se, ademais, que possa haver a separação entre os proprietários da empresa e aqueles que a controlam, ou tomam as decisões no seu dia a dia. Mas isso não gera turbulências ou contradições entre possíveis objetivos diferentes dos proprietários e dos administradores da firma, ${ }^{10}$ conforme se encerra o subitem: ${ }^{11}$ "Como veremos a seguir, esse objetivo [maximização do lucro], se interpretado de maneira apropriada, leva os administradores da empresa a escolherem ações do interesse dos proprietários” (Varian, [1996] 1999, p. 344).

\footnotetext{
${ }^{9}$ Essa é a ótica dos livros-textos de microeconomia na parte em que se discute o comportamento da empresa no estabelecimento de preço e produção em mercados competitivos e monopólicos. Em ambos os mercados o princípio é o mesmo: o da maximização condicionada.

${ }^{10} \mathrm{O}$ fato de que os administradores possam ter seus interesses particulares não invalida a questão de que devem procurar obter lucros, crescer e também atender as necessidades dos acionistas. O ponto é que lucros e crescimento se inter-relacionam. Outros objetivos e a distribuição de dividendos estão condicionados pelas oportunidades de investimentos lucrativos (Penrose [1959] 2006).

${ }^{11}$ É interessante mencionar que Marshall ([1920] 1982), um dos pais fundadores da teoria neoclássica, já havia alertado para a difusão na economia britânica da grande empresa organizada sob a forma de sociedade anônima e de potenciais dificuldades de os acionistas controlarem a atuação da equipe gerencial em seus diferentes níveis. A ausência de conflitos de interesses e a viabilidade dessa forma de empresa, segundo Marshall, seriam devidas a aspectos morais como a retidão e a honestidade dos administradores e que estariam se fortalecendo no ambiente de negócios, embora o autor não vá além dessas simples afirmações.
} 
Esse tipo de enfoque parece desconhecer ou não considerar contribuições seminais de estudiosos e historiadores empresariais na explicação do surgimento da grande empresa e da sociedade anônima na economia capitalista, como, por exemplo, Berle e Means ([1932] 1984), Chandler ([1959] 1998), entre outros. Em relação à obra de Berle e Means, uma das pioneiras na discussão da moderna sociedade anônima, cabe reproduzir as suas palavras no prefácio escrito em 1967, quando da revisão da edição original de 1932:

O deslocamento de cerca de dois terços da riqueza industrial do país [Estados Unidos] da propriedade individual para a propriedade de grandes empresas financiadas pelo público transforma radicalmente a vida dos proprietários, a vida dos trabalhadores e as formas de propriedade. O divórcio entre a propriedade e o controle, resultante desse processo, envolve quase necessariamente uma nova forma de organização econômica da sociedade. (Berle; Means, [1932] 1984, p. 3)

E em um parágrafo anterior a esse, ainda no prefácio do livro, consta: "Instituições como a sociedade anônima moderna não afetam apenas a vida econômica; seu estudo requer espaço [...] considerável na teoria econômica e na teoria política”.

A origem do enfoque neoclássico convencional pode ser encontrada em Marshall ([1920] 1982), com a sua noção de "firma representativa". Marshall estava preocupado com o equilíbrio de mercado ou o preço de equilíbrio, situação em que a oferta e a demanda de um determinado bem ou serviço se igualam. Marshall tentou explicar a formação do preço das mercadorias combinando a teoria do valor dos economistas clássicos em termos de custo de produção, ou seja, pelo lado da oferta, com a noção de valor subjetivo ou de utilidade dos marginalistas, que informaria a demanda dos consumidores e, assim, chegar ao preço de equilíbrio. Marshall questionava a primazia de um ou outro lado na explicação do preço, usando a metáfora das lâminas da tesoura, em que ambas seriam igualmente importantes no corte de uma folha de papel.Assim, tanto a oferta quanto a demanda tinham um papel a desempenhar (Hawkins, 1973).

Para gerar a curva de oferta positivamente inclinada, Marshall necessitava de uma teoria da produção. Nessa tentativa de elaborar tal teoria, ele vai se defrontar com contradições. Ao admitir a existência internamente à firma de retornos crescentes, como preconizado por Adam Smith por intermédio da divisão do trabalho e melhor organização da produção, isso levaria a uma 
queda nos custos normais de produção e, no limite, culminaria com uma posição monopolista de mercado. Mas isso seria incompatível com a impessoalidade do mercado, ou seja, com a concorrência perfeita. Por outro lado, para admitir tal impessoalidade, em que a firma não teria individualmente nenhum poder de mercado, seria necessário abandonar a permanência no tempo dos retornos crescentes. Para contornar esse dilema, Marshall usa tanto o argumento das árvores na floresta, onde as mais antigas vão morrendo e dando lugar a novas, quanto de que os herdeiros do empresário pioneiro não teriam o mesmo ímpeto e energia que o fundador. Vale aqui reproduzir com certa extensão suas palavras:

Mas aqui podemos aprender uma lição das árvores jovens da floresta, que lutam para ultrapassar a sombra entorpecedora das suas velhas concorrentes. Muitas sucumbem no caminho, e apenas poucas sobrevivem e essas poucas se tornam mais fortes cada ano, obtêm mais ar e mais luz à medida que crescem e, afinal, se elevam, a seu turno, acima das vizinhas e parecem querer se elevar sempre mais e tornar-se sempre mais fortes à proporção que sobem. Mas assim não acontece. Uma árvore durará mais tempo em pleno vigor e alcançará um tamanho maior que outra mas, cedo ou tarde, a idade se manifesta em todas. Embora as mais altas tenham melhor acesso à luz e ao ar do que as suas rivais, gradualmente perdem vitalidade, e uma após outra dão lugar a novas que, apesar de possuírem menos força material, têm a seu favor o viço da mocidade. (Marshall, [1920] 1982, p. 266)

[...] quando um homem conseguiu montar um grande negócio, é comum que seus descendentes não logrem [...] desenvolver a habilidade e a feição mental indispensáveis para continuar a empresa com o mesmo sucesso. $\mathrm{O}$ fundador da empresa provavelmente foi criado por pais dotados de um caráter enérgico, sob cuja influência pessoal foi educado, e entrou desde cedo em contato com as lutas e dificuldades da vida. Seus filhos, porém, principalmente se nasceram depois de ter ele enriquecido, e de qualquer sorte seus netos, são entregues aos cuidados de empregados domésticos que não possuem a mesma fibra dos que o educaram. E ao passo que a sua maior ambição talvez tenha sido ser bem-sucedido nos negócios, a dos filhos provavelmente será distinguir-se nos estudos ou na vida social. (Marshall, [1920] 1982, p. 255)

O resultado é que a firma não cresceria além de certo limite ótimo e nem se diferenciaria das demais: seria um "produtor típico" ou uma "firma representativa", a partir da qual se poderia calcular o custo normal de pro- 
dução para determinada atividade econômica. ${ }^{12} \mathrm{~A}$ firma, assim, estaria sujeita à ação de duas leis: a dos rendimentos decrescentes e a dos rendimentos crescentes. A primeira seria devida às limitações da natureza, em que um acréscimo na produção de produtos primários ou de matérias-primas seria inferior proporcionalmente em relação à quantidade dos recursos empregados para obter dita produção. A segunda seria decorrente da maior eficiência alcançada pela ação do homem na melhoria da organização da produção, como a divisão do trabalho e o emprego de maquinaria. Marshall ([1920] 1982) reconhece que a ação da primeira lei é mais afeita à atividade agrícola e menos à manufatura, e que nesta última atividade predominariam os retornos crescentes. Contudo, como se viu antes, Marshall impôs limites ao crescimento da firma, ou seja, restringindo o crescimento que resultaria dos rendimentos crescentes. Contudo, como assinalado por Sraffa ([1926] 1988) e Best (1990), para efeito de sua análise estática e de equilíbrio, Marshall vai supor que predomine a lei dos rendimentos decrescentes, de modo a conseguir gerar uma curva de oferta positivamente inclinada.

Há ainda uma questão adicional na análise marshalliana, mesmo admitindo a prevalência de rendimentos decrescentes. Para determinar o preço de equilíbrio de mercado de um produto por meio da interação entre oferta e procura, Marshall tem de supor a independência desses dois lados do mercado. Isso é feito pela suposição de ceteris paribus, ou seja, que as alterações produtivas em outros segmentos da atividade econômica não influenciam, nem são influenciadas, pelo que ocorre no mercado da atividade objeto de investigação. Entretanto, como Sraffa ([1926] 1988) mostrou, isso não necessariamente é verdadeiro. Quando há um aumento na demanda de uma dada mercadoria e cujo fator de produção que emprega tenha uso mais amplo, além daquele da mercadoria em análise, ou seja, em diversos outros setores industriais, o aumento do custo do fator devido ao seu uso mais intenso repercutiria também na elevação de custos de outras mercadorias que o utilizam. Se ocorrer que algumas dessas mercadorias sejam substitutas próximas ou complementares àquela em questão, isso afetaria a demanda da mercadoria analisada, de modo que não se pode supor a independência das curvas de oferta e de demanda dessa mercadoria particular e daí encontrar o seu preço de equilíbrio. Nesse caso não se aplicaria a análise de equilíbrio parcial, pois nem tudo que

\footnotetext{
${ }^{12}$ Alguns autores, como Bloch e Finch (2010), defendem que seja possível derivar em Marshall uma teoria da firma com características evolucionárias. Contudo, a visão da firma representativa foi o que predominou como interpretação do legado de Marshall.
} 
é ceteris é também paribus. O resultado dessas inconsistências é que, para Sraffa ([1926] 1982), a análise do valor da mercadoria em concorrência fica dessa forma prejudicada, devendo-se, então, voltar à velha teoria - clássica - que considerava o valor dependente apenas do custo de produção.

Essas objeções aos fundamentos neoclássicos da teoria marshalliana feitas por Sraffa são apenas um prenúncio de outras que viriam a seguir, embora sem negar de todo essa concepção teórica. Apenas para exemplificar, no âmbito da análise da concorrência, Joan Robinson ([1933] 1973) vai abandonar o arcabouço teórico da concorrência perfeita e desenvolver a sua Teoria da Concorrência Imperfeita, mantendo, contudo, a análise marginal e de equilíbrio. No caso do estabelecimento do preço mediante o emprego do princípio marginalista de maximização do lucro por intermédio da igualdade da receita marginal com o custo marginal, Hall e Hitch ([1939] 1988) vão contestar esse princípio com o auxílio de pesquisa empírica, em que mostram que as empresas não seguem essa regra, mas outro princípio, o do custo total (full cost pricing), em que se adiciona uma margem bruta de lucro sobre os custos variáveis de produção para chegar ao preço final da mercadoria.

Marshall dá por estabelecido que a empresa exista, sem se preocupar em explicar a sua natureza e a sua origem. Ele, como se viu, estava interessado em chegar à curva de oferta de mercado mediante o estudo do custo normal de produção de uma firma representativa. A ideia de que o mercado, então, é o único coordenador da atividade econômica por meio do sistema de preços vai ser posta em questão por Ronald Coase ([1937] 1996) com o seu clássico artigo, "The nature of the firm". No artigo, Coase vai mostrar que essa explicação é parcialmente verdadeira. A firma também tem um papel a desempenhar nesse processo. Ocorre que a firma, tal como tratada pela teoria então estabelecida, careceria de maior realismo. Para uma aproximação à realidade, seria necessário, segundo ele, entender a natureza e os limites dessa outra instituição particular: a firma. Coase considera que a firma e o mercado são instituições complementares no papel de coordenação da atividade econômica. Para ele, as transações de bens e serviços no mercado pelo sistema de preços têm custos além daqueles incorridos na produção dessas mercadorias. São custos ex ante e ex post às transações. Os primeiros referem-se à busca de informações sobre os preços relevantes, sobre características dos bens a serem adquiridos, entre outras. Os segundos dizem respeito ao monitoramento dos contratos e à sua judicialização ou o recurso à arbitragem, caso necessário. Uma maneira de contornar esses custos seria criar uma organização que produza a mercadoria 
e que economize esses custos, pois assim a própria organização - a firma teria, ela mesma, as informações relevantes. Ocorre que para isso é necessário que se estabeleça uma estrutura de governança de modo a administrar a atividade internalizada, a qual, como se disse, também tem custos para além daqueles de produção. A escolha entre um e outro modo de coordenação é uma questão de eficiência, ou seja, aquele que apresentar o menor custo. Nas palavras de Coase ([1937] 1996, p. 42., tradução nossa), também mencionadas em Best (1990):

Fora da firma, os movimentos dos preços dirigem a produção, a qual é coordenada através de uma série de transações no mercado. No interior da firma, essas complicadas estruturas de trocas pelo mercado são substituídas pelo empresário-coordenador, que dirige a produção. Está claro que esses são métodos alternativos de coordenar a produção.

O que limitaria que toda a produção fosse realizada por uma única firma, ou que a firma substituísse o mercado? Coase responde que a empresa encontra restrições em seu crescimento, pois à medida que ela se expande os custos internos em administrar a expansão também se elevam. Essas limitações se deveriam, entre outros motivos, a que a função empresarial ou gerencial estaria sujeita à ação de rendimentos decrescentes: "Naturalmente esse ponto limite é alcançado onde os custos de organizar uma transação extra na firma se igualam aos custos incorridos em realizar a transação no mercado aberto, ou aos custos de organizá-la por outro empresário” (Coase, [1937] 1996, p. 46, tradução nossa).

Dessa forma, à semelhança de Marshall, Coase mantém a ideia de que a firma não se expande indefinidamente e pode, então, aplicar o princípio marshalliano de substituição na margem. Ou seja, a firma se expandiria até o ponto em que - na margem - o custo de realizar internamente determinada atividade se iguale àquele que se teria caso ela fosse feita pelo mercado.

Embora Coase tenha procurado avançar em direção a um maior realismo em relação à dicotomia firma-mercado, ${ }^{13}$ restou, no entanto, explicar melhor o comportamento dos agentes econômicos e a operacionalização dos custos de transação, de modo a informar as suas tomadas de decisões. Isso é

\footnotetext{
${ }^{13}$ Contudo, Richardson (1972), em seu The organization of the industry, menciona que a dicotomia firma-mercado é muito simplificada para explicar a organização da atividade econômica, desenvolvendo a ideia de uma terceira forma: a cooperação empresarial.
} 
necessário para superar certo conteúdo tautológico que adviria da afirmação de que a opção por uma ou outra forma é porque é mais barato fazer assim.

Entretanto, apesar dessa tentativa feita por Coase em tratar mais especificamente desse ente institucional chamado firma, a sua análise, ao se centrar na transação e na maximização condicionada, não consegue dar conteúdo histórico ao seu objeto de investigação. ${ }^{14}$

Williamson ([1975] 1991; [1985] 1989) vai procurar aprimorar aquela contribuição de Coase. Para Williamson ([1975] 1991), os custos de transação resultariam tanto de fatores ambientais quanto de fatores humanos. No que se refere a estes últimos:

Sustento que [...] uma teoria sobre empresas e mercados mais completa do que Coase elaborou neste estudo pioneiro ["The nature of the firm"] requer outorgar maior atenção às características dos atributos elementares dos homens responsáveis por tomar decisões, das quais o oportunismo é uma e a racionalidade limitada é outra. (Williamson, [1975] 1991, p. 20, tradução nossa)

A racionalidade limitada é um conceito que Williamson ([1975] 1991) toma emprestado de pesquisas que vinham sendo desenvolvidas no campo da teoria da tomada de decisão aplicada à economia desde os anos 1950, e refere-se àquelas características comportamentais do indivíduo em suas ações econômicas (Simon, 1959; 1979). Estas últimas estariam condicionadas pela sua incapacidade em conhecer plenamente todas as alternativas possíveis em relação ao alcance de seus objetivos, à incerteza sobre o ambiente e à sua limitação cognitiva em processar e expressar todas as informações relevantes que informam suas tomadas de decisão. A racionalidade limitada é contrária à racionalidade substantiva, ou perfeita, da teoria neoclássica convencional, em que o agente tem pleno conhecimento das variáveis envolvidas e, então, maximiza sua função-utilidade.

Segundo Lazonick (1991, p. 207), o oportunismo é um conceito elaborado por Kenneth J. Arrow e que Williamson ([1975] 1991) aplica para explicar os custos de transação. É aquela situação em que uma das partes da

\footnotetext{
${ }^{14}$ Além disso, o mercado, ou a transação, é o âmbito da troca e não da produção. Como explicar a troca de uma mercadoria sem antes saber como foi criada (Ankarloo; Palermo, 2004)? O "make or buy" implica conhecer o produto a ser objeto de negociação por ambas as instituições: a firma e o mercado. Como aplicar essa regra para algo que ainda não está disponível à sociedade, estando, por exemplo, apenas no domínio de uma firma inovadora que não sabe a priori se o seu produto ou serviço será selecionado pelo mercado?
} 
transação age de maneira desonesta, com fraude, ou de forma dolosa, manipulando informações de modo a tirar proveito individual. A questão não seria tanto a assimetria de informações em si, mas o comportamento astucioso.

Os fatores ambientais referem-se às incertezas/complexidades do meio onde ocorrem as transações e que não podem ser consideradas em sua plenitude quando das tomadas de decisões pelos agentes, ou no estabelecimento de contratos na completa previsão de contingências. Por outro lado, essas transações podem ser realizadas por um pequeno ou um grande número de participantes em cada lado do mercado, com possibilidades de ganhos oportunistas, particularmente na presença de assimetria de informações. Haveria uma relação inversa entre o número de participantes e a presença de comportamento oportunista. Williamson ([1975] 1991), então, vai combinar a racionalidade limitada com a incerteza/complexidade, e o oportunismo com o pequeno número, para explicar as falhas de organização. $\mathrm{Na}$ presença de tais situações, é vantajoso estabelecer uma organização interna para gerir a transação, pois nesses casos a firma economizaria em racionalidade limitada na presença de incerteza/complexidade, bem como evitaria o oportunismo decorrente da existência de pequeno número.

Em estudos posteriores (Williamson, ([1985] 1989), o tema será aprofundado agregando aos fatores humanos - racionalidade limitada e oportunismo - a "especificidade de ativos", que é aquela situação em que os recursos objetos de transação apresentam conteúdos idiossincráticos, ou seja, que atendem necessidades particulares dos participantes e cujos usos alternativos são inexistentes ou produzem perdas quando de seu emprego. Em tais casos busca-se criar salvaguardas para preservar os investimentos realizados nesses ativos. Para Williamson ([1985] 1989, p. 40), essa "é a dimensão mais decisiva para a descrição das transações".

No que se refere à questão colocada por Coase de por que as atividades produtivas não seriam realizadas por uma big firm, em substituição ao mercado, Williamson também vai dar uma resposta semelhante, no sentido de que para ele as transações organizadas internamente à firma estariam sujeitas a rendimentos decrescentes:

[...] os poderes distintivos da organização interna se deteriorarão e se produzirão deseconomias transacionais à medida que aumenta progressivamente o tamanho da empresa e o grau de integração vertical, mantida constante a forma de organização. (Williamson, [1975] 1991, p. 141, tradução nossa) 
Williamson tece críticas à visão convencional da firma e aponta suas limitações. A consideração da firma como uma instituição tão importante quanto o mercado na coordenação da atividade econômica permitiu a Williamson, seguindo Coase, ser proeminente na criação do que denominou de uma "Nova Economia Institucional". Contudo, isso não significa que ele tenha abandonado o arcabouço teórico neoclássico. O próprio Williamson se coloca nessa posição quando afirma:"Os novos economistas institucionais recorrem à microteoria e, em sua maioria, consideram o que fazem mais como um complemento do que um substituto da análise convencional" (Williamson, [1975] 1991, p. 17, tradução nossa, grifo nosso). Williamson reforça ainda a proeminência dos custos de transação em vez da tecnologia no seu papel em determinar a configuração empresarial particular:

Se bem a relação da tecnologia com a organização siga sendo importante, dificilmente é determinante. [...] mantenho que as considerações transacionais, não as tecnológicas, são comumente as decisivas para determinar qual será o modelo de organização que há de se adotar, em que circunstâncias e por quê. (Williamson, [1975] 1991, p. 17-18, tradução nossa, grifo nosso)

A Nova Economia Institucional, conforme é enfatizado por Rutherford (1989), tem o seu desenvolvimento teórico realizado a partir de variadas contribuições de enfoque neoclássico (por exemplo, no que se aplica aos custos de transação em histórica econômica, visto em Douglas North, e à evolução organizacional, em Williamson), da teoria dos jogos e da corrente austríaca. Segundo ainda o autor, em nota de rodapé número 2 de seu artigo, embora Williamson se baseie também em fontes não neoclássicas, em essência ele pode ser considerado como filiado à corrente neoclássica.

O mesmo pode ser observado na obra de Hodgson ([1988] 1996), um destacado autor institucionalista. De acordo com Hodgson, a teoria dos custos de transação, ao não considerar os hábitos e as rotinas que as firmas desenvolvem e mantêm, e que informam as suas capacitações, torna-se incapaz de explicar a existência e a natureza da firma. Explicitamente afirma: "o tipo de análise apresentado por Coase e Williamson é essencialmente neoclássico, na medida em que não faz uso de normas e convenções e se baseia em um cálculo onipresente [ubiquitous] de 'custos"” (Hodgson, [1988] 1996, p. 206, tradução nossa).

O desconforto de Williamson com a microteoria convencional está em que os economistas se preocupam apenas com a organização do mercado, não 
se ocupando com aspectos internos da organização, ou da firma, os quais são deixados para os estudiosos em administração. Em 1982, no prefácio à edição universitária de sua obra, Williamson ([1975] 1991, p. 7, tradução nossa) estabelece:

No geral estuda-se a organização econômica como se o mercado e os métodos administrativos estivessem separados. A organização do mercado é competência dos economistas; a organização interna cabe aos especialistas na teoria da organização, e elas nunca convergem. Em Mercados e hierarquias sustenta-se que é possível entender as forças e os limites do mercado, assim como os métodos internos de organização, somente se se analisa cada um deles em relação ao outro. A atenção centra-se em economizar no custo de transação e não na tecnologia e nos custos de produção.

E prossegue:

Em contraste com o mecanismo padrão da economia neoclássica, o qual resulta relativamente pouco útil em seu intento em avaliar estruturas hierárquicas e processos de controle interno, a linguagem da economia dos custos de transação resulta muito mais proveitosa.

Contudo, a filiação neoclássica de Williamson é mantida não só pela sua análise estática e de equilíbrio. Ao fim e ao cabo, para ele a firma é resultado de "falhas de mercado". Caso os mercados fossem perfeitos - não apresentassem "falhas" -, não haveria necessidade de organização interna para administrar as transações. Williamson ([1975] 1991, p. 37, tradução nossa) afirma: "dou por estabelecido que "no princípio havia mercados"'. Ao abandonar a tecnologia como um fator importante na explicação para a existência da firma, Williamson perde a capacidade de entender a dinâmica do capitalismo e de suas instituições. ${ }^{15}$ Não há na teoria dos custos de transação, de acordo com crítica feita por Lazonick (1991, p. 195), espaço para deduzir o papel que a empresa exerce na mudança tecnológica e no desenvolvimento econômico. Ao se centrar nos custos de transação como unidade básica de análise, atribui-se à empresa uma atitude passiva, adaptativa, desconsiderando as motivações estratégicas na busca consciente em mudar o ambiente aos seus interesses. Assim, os investimentos em ativos específicos - por exemplo, com

\footnotetext{
${ }^{15}$ Ankaloo e Palermo (2004) avaliam que a explicação de Williamson para a existência e evolução das instituições na economia segue a cartilha neoclássica e não se sustenta teoricamente. Ao supor que "no princípio havia mercados”, o autor dá por estabelecido o que, antes, deveria explicar. Ao não o fazer, segundo os autores, Williamson incorre apenas em apologia.
} 
características inovativas -, em vez de serem considerados como fazendo parte da estratégica da firma em busca de vantagem competitiva no mercado, são, ao contrário, tratados como uma questão apenas de eficiência, minimizando os custos transacionais.

Assim, em que pese o esforço de Williamson em considerar o aparecimento de distintas formas organizacionais na indústria americana, como a empresa multidivisional, a conglomerada e a multinacional, o seu enfoque assume um conteúdo reducionista ao admitir que elas tenham origem unicamente em reduções nos custos de transação. Williamson discorda da visão desenvolvida por Chandler de que as formas organizacionais assumidas pela firma se devam a motivações estratégicas ou tecnológicas, e de que a organização hierárquica seja superior à organização de mercado. Para ele, essa maneira de ver a questão é incorreta. Esses dois tipos de coordenação - firma e mercado - coexistem em ativa justaposição, e o que define a escolha por uma forma ou outra é um assunto apenas de eficiência institucional comparada (Williamson, 1980; 1981).

A teoria dos custos de transação vai receber também restrições provenientes da corrente que vê a existência da firma não como uma questão de planejamento hierárquico para economizar em custos de transações, mas como um nexo de contratos, como assunto de agência, ou seja, para resolver interesses divergentes entre os participantes de um empreendimento. A ideia é que não tem sentido tratar a firma como sendo semelhante a um indivíduo, quase que lhe atribuindo características antropomórficas, que tem uma função-objetivo unitária definida. Para Jensen e Meckling ([1976] 1996, p. 108, tradução nossa), “a maioria das organizações, [incluindo a firma] são simplesmente fições legais que servem como um nexo para o estabelecimento de relações contratuais entre indivíduos".

Embora não neguem in totum a teoria de Coase dos custos de transação, Alchian e Demsetz ([1972] 1996) discordam da visão de que a firma é uma estrutura de governança que planeja e edita ordens no seu interior, como na afirmação de Coase ([1937] 1996, p. 41) de que um funcionário vai de uma seção à outra na firma, não porque foi orientado pelo sistema de preços, mas porque recebeu uma ordem para assim fazê-lo. ${ }^{16}$ Para os autores, seria ilusório supor que a firma tivesse esse poder. A relação da firma com os seus empre-

\footnotetext{
${ }^{16}$ Alchian e Demsetz ([1972] 1996, p. 83) consideram que a análise dos custos de transação apresenta também limitações ao não conseguir explicar, por exemplo, a formação da sociedade anônima, dentre outras formas empresariais.
} 
gados não é diferente daquela que o merceeiro tem com os seus consumidores. Nenhuma das partes da relação tem compromisso permanente uma com a outra. Esse vínculo pode ser rompido a qualquer momento (Alchian; Demsetz [1972]1996). Conforme ainda os autores, o problema diz respeito a como a organização hierárquica ou interna mede e controla a produtividade dos membros que trabalham em equipe na produção de um bem ou serviço. Argumentam que a produção em conjunto é maior do que a soma das produtividades obtidas individualmente. Contudo, em uma produção em grupo, com indivíduos agindo autonomamente, é difícil, ou muito custoso, ter a produtividade de cada membro identificada de modo a ser somada para obter o produto total, bem como conhecer qual deles está porventura trabalhando menos do que o esperado. O mercado não teria como controlar com eficiência essa produtividade mediante trocas bilaterais entre cada fator que participaria em um trabalho conjunto, pois teria que se saber a priori qual seria o grau futuro do possível comportamento indolente (shirking) desses participantes. Ao organizar essa equipe em uma instituição chamada empresa, torna-se mais fácil ou factível estimar a produtividade marginal individual e atribuir a sua devida recompensa monetária, mediante a observação e o disciplinamento da conduta dos membros da equipe, minimizando o comportamento indolente. Na constituição dessa turma de trabalho, poderia ser atribuída a alguém (um dos proprietários, segundo os autores) a tarefa de centralizar a contratação de cada participante, em troca do recebimento de uma remuneração, enquanto resíduo, em relação às produtividades marginais individuais (Alchian; Demsetz, [1972] 1996).

Na opinião de Jensen e Meckling ([1976] 1996), a produção em equipe, se bem seja importante, é apenas parte da estória. É a relação de agência ao estabelecer um contrato que dá sentido à existência da firma, e isso vale para qualquer tipo de organização. De acordo com Jensen e Meckling ([1976] 1996, p. 106, tradução nossa):

Definimos uma relação de agência como um contrato em que uma ou mais pessoas (o(s) principal(s)) contrata outra pessoa (o agente) para realizar algum serviço de seu interesse, o que envolve a delegação ao agente de alguma autoridade nas tomadas de decisões. Se ambas as partes na relação são maximizadores de utilidade, haverá boas razões para acreditar que esse último nem sempre agirá no melhor interesse do principal. O principal pode restringir os desvios em relação aos seus interesses mediante o estabelecimento de incentivos apropriados em beneficio do agente, 
incorrendo, assim, nos custos de monitoramento para que este limite as suas atividades desviantes.

Esses custos de agência são definidos como os gastos de controle feitos pelo principal, os gastos em garantias dadas pelo agente, bem como as perdas residuais que são as reduções de ganhos ou perdas de bem-estar sofridas pelo principal (Jensen; Meckling, [1976] 1996, p. 107).

Esses desenvolvimentos teóricos, que veem a firma como nexo de contratos, mantêm-se igualmente sob os cânones neoclássicos da maximização e do individualismo. Jensen e Meckling ([1976] 1996) inclusive lamentam - de acordo com sua interpretação - que o estudo de Simon (1959), ao considerar a conduta "satisficing", tenha sido considerado como negando o comportamento maximizador e, por isso, estaria sendo mal-empregado.

Seja como for, não há nesses enfoques neoclássicos esforços consistentes no sentido de discutir o surgimento e as transformações históricas que essa instituição - firma - tem experimentado e o seu papel no desenvolvimento econômico.

Olhar a firma em seu movimento no tempo, com seu comportamento estratégico, é um esforço teórico que vem sendo feito por autores que consideram o enfoque neoclássico como não oferecendo conceitos úteis para tratar com essa instituição do capitalismo.

\section{A abordagem heterodoxa da firma}

O enfoque heterodoxo da firma se encontra em processo criador, não possuindo ainda um corpo teórico unificado de aceitação geral.É uma teoria em construção que vem recebendo contribuições variadas. O que dá unidade a esse enfoque, e que distintos autores compartilham, é primeiramente uma rejeição à abordagem neoclássica ortodoxa e às suas diferentes nuances, devido à limitação dessa vertente teórica de compreender os fenômenos econômicos, incluído aí a firma. Em segundo lugar, a visão heterodoxa da firma é feita por meio da opção analítica por uma metodologia dinâmica e de desequilíbrio, incorporando elementos de natureza histórica. Apesar dessa base comum, a variedade de interpretações existentes nessa corrente deve-se em parte às características da firma que são privilegiadas pelas abordagens particulares. Nesse sentido, a revisão da literatura está longe de ser exaustiva. O que se propõe é explicitar a seguir a ideia básica desse enfoque heterodoxo. 
Um dos estudos pioneiros nessa direção é o de Penrose (1959 [2006]). Ao contrário da teoria neoclássica, em seu ideal na busca de um estado em que a firma alcance um tamanho ótimo e de equilíbrio, para Penrose tal situação é impraticável. Não existe tal coisa como um "tamanho ótimo" que restringiria a expansão da firma. ${ }^{17} \mathrm{~A}$ firma também não se encontra limitada em sua trajetória de expansão pelo produto corrente que vende no mercado. ${ }^{18}$ O mercado em que a firma atua, ao se esgotar ou perder dinamismo, leva a que ela diversifique sua estrutura produtiva e trilhe novos caminhos de crescimento. $\mathrm{O}$ que a firma enfrenta, segundo Penrose, são os limites à sua taxa de expansão e não ao seu tamanho. Esse último, como aponta Penrose ([1959] 2006, p. 34), é apenas um subproduto de seu processo de crescimento. Best (1990), um dos principais adeptos da visão penrosiana, chega a extremos ao afirmar que a contribuição daquela autora é a única a fornecer categorias conceituais capazes de entender a dinâmica interna da expansão empresarial. $\mathrm{Na}$ sua avaliação, Penrose trata essencialmente com a dinâmica econômica.

Dentre as contribuições de Penrose ([1959] 2006) está a sua concepção dos recursos produtivos que a firma possui. Em vez de tratar esses recursos de maneira tradicional, como na teoria neoclássica, ou seja, como "fatores de produção", com determinadas características e com distintas funções específicas na produção, Penrose adota o conceito de "serviços dos recursos", recursos esses que podem ser empregados em atividades variadas. São os "serviços" que esses recursos podem produzir que vão delimitar o escopo de atuação da firma e os seus limites de expansão. ${ }^{19}$

\footnotetext{
17 Situação essa representada nos livros-texto de microeconomia pela curva de custo médio em forma de "U”. Isso implica, como já mencionado anteriormente, aceitar que as empresas trabalhem sob a ação da lei dos rendimentos decrescentes. Contudo, mesmo sob análise estática, se a tecnologia e a organização da firma forem tais que no segmento relevante de produção ocorram rendimentos constantes, ou que a firma se defronte com uma estrutura de custos na forma de um "J" invertido, com o segmento horizontal do "J" paralelo ao eixo das abscissas, então existem diferentes tamanhos de empresas que são igualmente factíveis, e não apenas um deles como sendo ótimo. Isso explicaria muito mais a heterogeneidade estrutural dos mercados, com as empresas apresentando diferentes tamanhos, como se observa empiricamente, do que firmas com tamanhos semelhantes ou ótimos.

${ }^{18}$ Mercado entendido em suas dimensões de produto e geografia.

${ }^{19}$ Com inspiração em Penrose, a partir do início dos anos 1980 desenvolve-se no âmbito da administração estratégica a visão da firma denominada: The resource-based view (Visão da firma baseada em recursos) (Wernerfelt, 1984). Para essa corrente, as vantagens competitivas da firma estariam baseadas na posse de recursos particulares, tangíveis e/ou intangíveis, - marcas, tecnologia, entre outros - e que seriam dificeis de serem imitados por concorrentes, permitindo-lhe assim obter rendas sobre esses recursos. Esse enfoque ampliou as possibilidades estratégicas, além do enfoque segundo Porter ([1985] 1989), com suas vantagens competitivas assentadas nos produtos que a empresa vende no mercado. Em que pese a inspiração penrosiana, Nonaka, Toyama e Nagata (2000) avaliam que os autores dessa abordagem não avançam na constituição de uma teoria dinâmica da firma, pois não explicam como esses recursos são criados e se modificam com o tempo. Sendo assim, os autores arrolam essa visão da resource-based view junto com os enfoques neoclássicos convencionais e dos custos de transação.
} 
A concepção da firma na análise de Penrose é de uma unidade de planejamento com atividades gerencial e administrativa no desenvolvimento dos serviços dos seus recursos produtivos em direção a um caminho de expansão escolhido. ${ }^{20}$ Segundo Best (1990), a firma penrosiana mina a ideia neoclássica de que o sistema de preços contém todas as informações relevantes para uma eficiente alocação de recursos. Não são os preços relativos no mercado em si que determinam a combinação ótima de recursos no interior da empresa. Essa combinação é resultado de trabalho em equipe, com as diferentes capacitações individuais nesse ambiente sendo coordenadas e utilizadas de acordo com um plano estabelecido de expansão. A forma organizacional posta em prática é particular à empresa, e a produtividade individual de qualquer recurso é mais uma decorrência da produção coletiva do que simplesmente a soma de produtividades de fatores consideradas em abstrato. Assim, seguindo Penrose, não faz sentido falar de uma produtividade marginal de um fator de produção existente no mercado, cuja quantidade a ser adquirida - na margem - dependerá do valor do produto marginal produzido por esse fator comparado com o seu preço de mercado.

A diversificação produtiva é o caminho escolhido pela empresa penrosiana para dar vazão ao seu potencial de crescimento. ${ }^{21} \mathrm{~A}$ direção da diversificação estaria condicionada pela sua área de atuação tecnológica, que, inclusive, pode ser alterada à medida que se diversifica, e pelas áreas de comercialização em que escoa a sua produção, no sentido de grupos de consumidores ou segmentos de mercado que consegue alcançar. Mas o processo de diversificação não é ilimitado. À medida que a firma amplia a sua gama de linhas de produtos, torna-se cada vez mais difícil alargar sua capacitação gerencial com experiência para desenvolver e/ou adquirir recursos com potenciais a serem aplicados em oportunidades lucrativas. É a limitação de sua capacidade gerencial que vai estabelecer, então, uma fronteira que restringirá a sua taxa de crescimento.

A realidade capitalista à qual Penrose ([1959] 2006) espera que sua teoria possa dar conta é aquela em que atuam empresas privadas em atividades industriais, nas quais se destaca na organização econômica o aparecimento de firmas constituídas sob a forma de sociedades anônimas, a partir do final do século XIX. Penrose, na introdução, escrita em 1995, à terceira edição de sua

\footnotetext{
${ }^{20}$ Essa concepção contrasta com a visão neoclássica da firma. Pode-se dizer que a firma no neoclassicismo é um ente amorfo e vazio. Como Penrose avalia: "As firmas dos economistas na 'teoria da firma' não correspondem de forma alguma às instituições econômicas tomadas como firmas pelas pessoas comuns" (Penrose, [1959] 2006, p. 39).

${ }^{21}$ Ver também Guimarães (1982), capítulos 2 e 5.
} 
obra, reconhece a contribuição de Chandler contida em Strategy and structure, publicada em 1962, que, segundo ela, traz evidências da aplicabilidade de sua teoria, pelo menos no ambiente industrial americano analisado por Chandler. E ao encerrar aquela introdução, Penrose menciona o surgimento das redes de firmas de diferentes formas e, sob esse aspecto, as dificuldades em determinar as fronteiras das firmas individuais e o significado da concorrência nos mercados. Questiona, então, se não seria necessária uma nova "teoria da firma" (ênfase salientada por ela) para tratar dessa situação.

Já haviam sido mencionados, na primeira seção deste artigo, os trabalhos de Chandler acerca do surgimento da grande empresa na estrutura industrial americana. Como ali foi referido, Chandler move-se diretamente na história. Em seus estudos, analisa empiricamente o comportamento de várias empresas pertencentes, em particular, à indústria americana.

Em um de seus textos, escrito no início da década de 1990, Chandler (1992) menciona que, como historiador empresarial, em seus estudos empíricos, não se preocupou em definir o que seja uma firma, pois nunca encontrou problemas em localizar e coletar informações em centenas delas. Mas, segundo ele, para os economistas a identificação do que seja e o que faz uma firma constitui-se em um problema assaz complexo. $\mathrm{O}$ artigo, então, faz um retrospecto da formação da grande empresa e contrasta teoricamente a sua visão de firma com a de outras teorias, nomeando-as essas últimas como: neoclássica (a convencional, como aqui está sendo referida) custos de transação, agente-principal e evolucionária. A questão, para Chandler, é explicar as semelhanças ou regularidades no início histórico e no contínuo desenvolvimento de empresas em diferentes indústrias, e como as teorias da firma dariam conta dessas transformações observadas na estrutura industrial.

$\mathrm{O}$ surgimento da grande empresa na estrutura produtiva americana e em outros países - Alemanha e Inglaterra, entre outros - no final do século XIX em diante deu-se no aproveitamento de oportunidades econômicas criadas por um conjunto de fatores, como a constituição de amplos mercados, revoluções nos meios de transportes e comunicações, propiciando o surgimento de inovações tecnológicas, as quais passaram a se constituir no núcleo da chamada II Revolução Industrial. Chandler (1992) identifica dois movimentos nessa direção de expansão. O primeiro ocorre por meio da integração vertical para frente e para trás com vistas a garantir o suprimento de insumos e matérias-primas e dar saída à produção mediante canais próprios de distribuição e marketing. Isso permitiu às firmas obter vantagens por economias 
de escala e de escopo. ${ }^{22} \mathrm{O}$ segundo movimento ocorre com a diversificação de mercados de produtos e de indústrias relacionadas, bem como geográficos, inclusive com atuação no exterior.

Para que fosse possível tirar proveito das oportunidades que se abriam, as firmas tinham que desenvolver capacidades organizacionais para lidar com estruturas empresariais complexas. Era preciso gerenciar vultosos investimentos em estruturas fisicas, organizar equipes de trabalho e controlar o fluxo de insumos, o marketing e a distribuição de produtos em distintos mercados geográficos. As empresas que primeiramente realizaram os investimentos necessários na fabricação, na distribuição e em equipes gerenciais em seus diferentes níveis - que Chandler (1992) denomina "first movers"-, foram as que ganharam a liderança nos mercados. Essas empresas que obedeceram à "lógica do empreendimento industrial" passaram a ser protagonistas nos mercados doméstico e internacional por décadas, sobreviveram a variadas crises mundiais e destacam-se ainda hoje (Chandler [1990] 1998).

Embora Chandler (1992) nutra certa simpatia pela teoria dos custos de transação por incluir na análise, por exemplo, a especificidade de ativos, a sua visão de firma é diferente e a transação, segundo ele, não explicaria a constituição e o desenvolvimento das empresas, como relatado acima. Para Chandler, é a firma, em vez da transação, que deve ser considerada como a unidade básica de análise. ${ }^{23}$ Nas suas palavras:

Para mim [o importante] é a firma e os seus ativos humanos e físicos [em vez da transação]. Se a firma é a unidade de análise, em vez da transação, então a natureza específica dos equipamentos e das capacidades da firma tornam-se os fatores mais importantes na determinação do que será feito pela firma e pelo mercado. (Chandler, 1992, p. 85-86, tradução nossa)

Na ótica de Chandler (1992), a teoria evolucionária está mais bem capacitada em explicar as mudanças havidas na estrutura industrial e nas empresas modernas, pois essa corrente também compartilha a visão de que é a firma baseada nas suas capacitações dinâmicas que deve ser a unidade de análise a explicar a mudança estrutural e o crescimento. Chandler reconhece em Nelson e Winter ([1982] 2005) um pioneirismo na formulação de dita teoria.

\footnotetext{
${ }^{22}$ Ver, em particular, Chandler (1990).

${ }^{23}$ Para Chandler (1992), tanto a teoria dos custos de transação como a teoria do agente-principal baseiam-se em assimetria de informações. A primeira, em relação aos contratos estabelecidos nas transações; a segunda, nos contratos entre o agente e o principal ou entre o proprietário e os gerentes.
} 
Cabe aqui citar Chandler mais uma vez, quando encerra o seu texto fazendo uma avaliação das categorias analíticas capazes de explicar o surgimento e o processo de expansão de firmas nas principais economias industrializadas desde o final do século XIX:

\begin{abstract}
$\mathrm{Na}$ busca desse objetivo estou convencido que a unidade de análise deve ser a firma, em vez das transações ou de relações contratuais por ela estabelecidas. Somente mediante o foco na firma pode a teoria microeconômica explicar por que esta entidade legal, que contrata, que transaciona, tem sido o instrumento nas economias capitalistas para realizar os processos de produção e distribuição, para aumentar a produtividade, para impulsionar a transformação e o crescimento econômico. Somente por meio do foco na firma pode a teoria predizer o seu contínuo papel como um instrumento de transformação e crescimento econômico, assistir políticas de desenvolvimento e medidas para manter a produtividade industrial e a competitividade em uma economia crescentemente globalizada. (Chandler, 1992, p. 99, tradução nossa)
\end{abstract}

A teoria evolucionária considera a firma inovativa como uma instituição básica em economias capitalistas. É a inovação em vez da alocação de recursos que deve ser a preocupação central para entender a dinâmica desse sistema de produção social (Nelson; Winter, [1982] 2005). Ao focar a firma, as características distintivas que devem ser consideradas dessa instituição, como também já haviam sido reconhecidas por Chandler (1992), referem-se às suas capacitações organizacionais construídas por aprendizado contínuo. As capacitações estão plasmadas em uma hierarquia de rotinas que a firma estabelece no seu dia a dia na realização de produção, distribuição, $\mathrm{P} \& \mathrm{D}$, entre outras funções, o que inclui também suas estratégias em busca de vantagens competitivas. A procura por oportunidades em novos produtos, processos e serviços, é feita com base em seu conhecimento acumulado, nos esforços próprios de pesquisa e na aquisição de conhecimentos pela interação com outras instituições, como universidades, fornecedores, consumidores e institutos de pesquisa. A ideia de que as ações dos agentes econômicos são guiadas por instituições - sejam as organizacionais, sejam aquelas provenientes de hábitos, normas sociais, rotinas, entre outras - em vez do comportamento otimizador dos indivíduos em busca de seu auto interesse, como prescreve a teoria neoclássica, é defendida também por adeptos da corrente Institucionalista, tal como em Hodgson ([1988] 1996).

Em ensaio no qual procura mostrar por que as firmas são diferentes 
entre si, em vez de se distribuírem uniformemente na atividade econômica, Nelson ([1991] 2006) identifica as características básicas da firma como sendo a sua estratégia, a sua estrutura, e as suas capacitações ou aptidões dinâmicas. A influência para a compreensão dessas diferenças, particularmente em relação às estratégias das firmas, Nelson credita aos trabalhos dos estudiosos do campo da administração empresarial. Esses estudos constatam que há diferenças nos comportamentos e desempenhos de empresas, mesmo em um mesmo ramo de produção. ${ }^{24}$

No tratamento da firma em seu comportamento discricionário individual, Nelson ([1991] 2006) chama a atenção para que se leve em conta também a influência do ambiente econômico - particularmente da concorrência - a que ela está sujeita, embora o seu objetivo maior seja explicitar o porquê das diferenças entre as firmas. ${ }^{25}$

A estratégia a que Nelson se refere como sendo um dos atributos da firma não tem relação com aquela dos adeptos da teoria dos jogos, mas com a utilizada pelos historiadores e estudiosos de administração. Trata-se, em linhas gerais, da definição dos seus objetivos e da estrutura ou dos meios que empregará para alcançá-los. A maneira como isso será feito irá depender de suas percepções das oportunidades, dos recursos que possui e do ambiente de seleção onde atua. Nessa situação, como Nelson ([1991] 2006) enfatiza, não há nada a priori que garanta que os caminhos escolhidos sejam "ótimos" e, inclusive, podem até mesmo carregar consigo elementos que ponham em risco a sua própria sobrevivência.

O conceito de estrutura está em linha com a postulação chandleriana e se refere à forma organizacional que a firma estabelece para arranjar as suas diferentes funções - produção, distribuição, marketing, entre outras - e como realiza a governança dessa estrutura, de modo a dar efetividade às decisões adotadas. Diferentes estratégias irão requerer estruturas adequadas. Por exemplo, uma firma de calçados que trabalhe subcontratada, executando a manufatura de um produto cuja marca e comercialização são detidas pela empresa subcontratante, não necessita possuir uma estrutura com um departamento

\footnotetext{
${ }^{24}$ Essa preocupação dos estudos em administração estratégica centrada na empresa difere daquela dos economistas, particularmente de raiz neoclássica, que tratam as firmas como semelhantes e que estão interessados no ambiente em que atuam ou no seu desempenho agregado, ignorando o que fazem as empresas nas suas individualidades (Nelson, [1991] 2006).

${ }^{25}$ Reconhece que o livro de Chandler, Scale and scope, e o de Michael Porter, The competitive advantage of nations, ambos de 1990, são dos poucos a estabelecerem essa ponte, embora ainda apresentem limitações sobre as diferenciações empresariais sob a perspectiva dos economistas (Nelson, [1991] 2006).
} 
de design, de marketing e canais de distribuição e vendas do produto. Contudo, se alterar a sua estratégia e passar a atuar com marca própria junto ao consumidor final, então uma estrutura semelhante àquela se fará necessária.

As rotinas organizacionais que a firma desenvolve e a hierarquia que estabelece entre elas é o que vai dar conteúdo às capacitações ou aptidões dinâmicas essenciais da firma para inovar. Esse é o conceito-chave para a teoria evolucionária da firma proposta por Nelson e Winter, e outros autores. Em seu livro, Nelson eWinter ([1982] 2005) realizam uma discussão mais minuciosa do significado das rotinas e os seus diferentes tipos - para produzir, inovar, investir - que guiam o comportamento das empresas, em vez da maximização. Dado que inovar é crucial para a sobrevivência da empresa, desenvolver capacitações nessa área é o que determina as vantagens competitivas que consegue alcançar.

A ideia de que a vantagem competitiva da firma está baseada na criação de capacitações é preconizada também por autores que discutem administração estratégica.Teece, Pisano e Shuen (1997), com o seu enfoque das “dynamic capabilities", defendem que a conquista e manutenção de vantagem competitiva está muito mais vinculada aos esforços internos da firma do que no ambiente ou na estrutura de mercado, como preconizam as correntes das forças competitivas e do conflito estratégico. Para eles, em um ambiente onde a concorrência pela realização do valor adicionado é comandada basicamente por inovações tecnológicas que se alteram rapidamente, a vantagem competitiva da firma irá depender do modo como ela explora - coordena e combina - as suas competências e os seus recursos específicos, particularmente aqueles dificeis de serem clonados pelos concorrentes, condicionados pelo caminho de crescimento adotado. O posicionamento competitivo, mais do que estar baseado em elementos da estrutura de mercado ou em movimentos estratégicos, estaria assentado em fatores que a firma endogenamente consegue desenvolver. O que a firma faz ou deixa de fazer não depende tanto das oportunidades que a ela se apresentam, mas da maneira como ela cria as competências para tirar proveito da situação.

Igualmente, Lazonick (2003) reforça a ideia de que a empresa, em sua dimensão inovativa, é que deve ser a unidade social básica de análise, a qual integra muitos indivíduos em um processo coletivo de inovação. Para isso é necessário combinar teoria econômica e história. ${ }^{26}$ Para ele, as transformações

\footnotetext{
${ }^{26} \mathrm{O}$ autor propõe, então, o conceito de "social conditions of innovative entreprise" (as condições sociais da empresa inovativa) para tratar a questão das transformações econômicas capitalistas.
} 
tecnológicas e de mercado existentes por meio do processo de inovação industrial requerem igualmente a transformação das estruturas organizacionais (que envolvem aspectos comportamentais, estratégicos e cognitivos) e institucionais (instituições sobre o mercado de trabalho, de regulação e de financiamento) que limitam ou promovam a utilização dos recursos produtivos em dado momento do tempo na produção de mercadorias de maior qualidade e menor custo em relação àqueles praticados até então, e de como essas estruturas interagem entre si.

Assim, a perspectiva "social conditions of innovative entreprise" [condições sociais da empresa inovativa] busca entender a interação dinâmica entre as empresas e o ambiente institucional em que atuam, bem como as implicações dessa interação para a transformação das condições tecnológica e de mercado em diferentes atividades industriais. (Lazonick, 2003, p. 38, tradução nossa)

Como as condições sociais que promovem ou limitam a inovação mudam com o tempo e são particulares aos diferentes ramos de atividade econômica, é necessária uma metodologia que leve em conta a transformação histórica dessas condições. Assim, a discussão sobre o desenvolvimento econômico requer uma teoria do papel da firma inovativa, de modo a explicar as mudanças observadas ao longo do tempo. Para isso, ao contrário do enfoque neoclássico, é necessária uma metodologia de análise que integre história e teoria econômica (Lazonick, 2003).

O padrão de competição que domina no mercado de atuação da empresa irá definir também as capacitações necessárias para que ela sustente sua vantagem competitiva. Firmas que concorrem em preços devem ter capacitações em estabelecer inovações para elevar a produtividade e reduzir custos. Caso concorram em outros atributos do produto, como design, marca, serviços pós-vendas e outros, então as capacitações necessárias para inovar nessa direção serão as desejadas. Igualmente, se for bem-sucedida em seu departamento de P\&D no desenvolvimento de uma nova tecnologia capaz de revolucionar o mercado, então, ganhará vantagens de "first mover". Essas aptidões dependem da história de "vida" da empresa, de sua experiência e conhecimento acumulados, dos ativos e recursos específicos a que pode ter acesso e que sejam dificeis de serem copiados pelos concorrentes, entre outros fatores.

Ao se olhar as firmas sob a ótica evolucionária, percebe-se que os elementos que lhes dão identidade, por serem particulares à sua organização, irão diferenciá-las entre si nos mercados. Esse padrão está mais próximo da 
norma empírica observada do que a homogeneidade empresarial preconizada pela teoria neoclássica. Na luta pela sobrevivência, aquelas empresas que conseguem desenvolver capacitações inovativas que lhes permitam atender com sucesso o mercado corrente, ou enveredar por novos caminhos, irão se expandir. As que não conseguem acompanhar as inovações serão eliminadas da contenda. ${ }^{27}$ Obviamente, que ao longo do tempo é possível que se estabeleça um padrão organizacional dominante a orientar as escolhas empresariais. A história do sucesso industrial de empresas mostra isso, conforme já referido em Chandler. É com essa concepção de firma, de acordo com Lazonick (1991), que se consegue entender por que as empresas americanas, a partir do final do século XIX e início do século XX, desbancaram as suas congêneres inglesas, permitindo a hegemonia dos Estados Unidos diante da Inglaterra na arena internacional, bem como o surgimento de empresas japonesas a partir dos anos 1970, com forte poder competitivo internacionalmente.

Analisando a organização industrial japonesa, Aoki ([1988] 1990) atribui o sucesso de suas empresas em setores industriais importantes, aos seus métodos de organizar e coordenar a produção. Comparando o que ele chamou de "empresa-J" (japonesa) com a "empresa-A" (americana), constatou que as estruturas organizacionais nipônicas eram mais horizontais e menos hierárquicas, com flexibilidade funcional dos trabalhadores no chão de fábrica, em face das formas hierarquizadas e trabalhadores especializados das firmas americanas, pondo em xeque a competitividade destas últimas, bem como diante de outras nações líderes em mercados relevantes no comércio exterior.

Enfim, a noção de firmas que não se diferenciam significativamente entre si, cujo único objetivo é a maximização de sua função-utilidade, sujeita às restrições de custos e de mercado, e onde a história está ausente - como o faz a teoria neoclássica - não é capaz de dar conta das transformações observadas no desenvolvimento capitalista. Para entender as mudanças econômicas havidas nesse sistema e o seu desenvolvimento ao longo do tempo, é necessário ter uma concepção de firma em que a metodologia de pesquisa integre economia e história, em que a abordagem seja dinâmica, e que se admita que na trajetória dessa instituição os caminhos percorridos não sejam devidos apenas a pressões externas ao funcionamento do sistema, ou fruto do acaso, mas que se originem de seus próprios esforços de sobrevivência por meio, particularmente, da inovação.

${ }^{27}$ Como salientado por Schumpeter ([1942] 1984), na luta competitiva há ganhadores e perdedores. 


\section{Síntese e considerações finais}

A firma é uma instituição central do sistema capitalista, pois é por meio dela que, de um modo geral, bens e serviços são criados e lançados no mercado. A sua feição moderna, contudo, é resultado de um longo processo histórico, cuja origem remonta à época da I Revolução Industrial.Até então, os bens eram produzidos de maneira artesanal, com as atividades produtivas sendo coordenadas por mestres-artesãos, empregando aprendizes que passavam a com eles conviver em seus próprios locais de moradia.

A revolução tecnológica por meio da máquina a vapor, do tear mecânico, do ferro e do aço, com os seus impactos na estrutura econômica e social, permitiu o estabelecimento de manufaturas em locais distintos daquele da moradia dos indivíduos envolvidos na produção de mercadorias. A instituição criada, chamada firma, por se mostrar eficiente no processo de acumulação de capital, difunde-se e torna-se central no tecido produtivo capitalista. Até por volta do final do século XIX, essa instituição era de pequeno porte e atuava basicamente em mercados locais tanto de produtos finais quanto de matérias-primas. A passagem do pequeno estabelecimento para a grande empresa é uma mudança não só em tamanho, mas também qualitativa. Esse tipo de empresa surge ao final do século XIX, principalmente na indústria americana, aproveitando as oportunidades oriundas da formação de aglomerações populacionais urbanas, da revolução dos meios de transporte e comunicação e de novas tecnologias da II Revolução Industrial, como a eletricidade e as empregadas, entre outras, nas indústrias automobilística e química. A criação de novas estruturas organizacionais para explorar as economias de escala e de escopo nesse novo ambiente permitiu que essas grandes empresas dominassem mercados, desbancassem rivais por meio de concorrência oligopolista e, inclusive, alçasse os Estados Unidos como potência internacional desde o alvorecer do século XX.

No âmbito da ciência econômica, a firma tem permanecido envolta em um tipo de névoa teórica, embaçada por controvérsias conceituais, metodológicas e por visões de mundo. Podem-se identificar, de maneira simplificada, dois campos teóricos em disputa: neoclássicos e heterodoxos. O que dá unidade a cada um deles é a semelhança da metodologia de análise e o enfoque analítico empregado pelos praticantes em cada corrente. Por teoria neoclássica entende-se aqui a ortodoxia e suas ramificações. No estudo da firma, a matriz é a teoria ortodoxa convencional, que domina o ensino pelos manuais de microeconomia, seguida pelas suas variantes mais salientes e que 
se pretendem mais realistas: a teoria dos custos de transação e a abordagem agente-principal. A heterodoxia, por sua vez, tem um de seus destaques na corrente evolucionária ou neoschumpeteriana, cujo pilar conceitual reside na inovação.

O que caracteriza a corrente neoclássica é o seu enfoque analítico,com uma metodologia que privilegia o individualismo - firma ou consumidor - e a abordagem estática e de equilíbrio. A teoria econômica construída sob essa base prescinde da história. O mundo econômico é naturalizado. Os agentes econômicos - como a teoria os chama - se apresentam um diante do outro sem passado, a sua posição no processo produtivo é distinguida apenas pelas funções ali exercidas, mas são todos iguais: proprietários de fatores de produção. As relações sociais estabelecidas na sociedade não cabem nesse tipo de análise, pois se acredita que não influenciariam o resultado econômico. Os agentes econômicos - a firma, no caso - apenas se adaptam aos movimentos impessoais do mercado e a eventos externos a ele em busca de um equilíbrio. A firma e os indivíduos são entes calculistas e otimizadores que respondem apenas aos seus interesses e aos sinais emitidos pelo sistema de preços, que os guiam.

O enfoque heterodoxo, por sua vez, trilha um caminho analítico distinto. Nele são privilegiados a dinâmica e o desequilíbrio, e a inovação que produz esse movimento é resultado de um processo coletivo de criação. Como tal, para essa abordagem, o mundo econômico é um mundo em transformação, em mutação, em que o hoje carrega as sementes do passado e condiciona também sua trajetória futura. O equilíbrio é uma quimera. Em vez de procurar se adaptar às condições dadas de mercado, a firma na visão schumpeteriana/ evolucionária tem um papel estratégico em suas ações na busca em superar as restrições encontradas, por meio da inovação. É a mudança estrutural e não as condições de equilíbrio o que dirige a máquina capitalista. Para dar conta desse mundo que evolui e se transforma é necessário combinar teoria econômica e história. Firma e mercado são instituições com passado, resultado de um processo de transformação, cujos elementos que lhe dão movimento resultam da própria dinâmica de funcionamento do sistema capitalista. Nesse ambiente que se caracteriza por ser incerto e pela instabilidade que lhe é inerente, não há lugar para o comportamento otimizador e o equilíbrio. Para sobreviver e crescer no mercado, a firma se vê compelida constantemente a desenvolver novos conhecimentos, ou seja, em inovar - processo esse que se manifesta em novos produtos, novas formas de produzir e em novos serviços. 
Como bem assinalou Schumpeter, a concorrência por preço capta muito pouco da dinâmica econômica. O que dá movimento a uma economia capitalista são suas ondas perenes de destruição criadora. Nesse processo, nem todas as firmas são bem-sucedidas, algumas ficam pelo caminho.

O debate teórico sobre a firma ainda está em curso. Enquanto o capitalismo for capitalismo, as suas contradições e interesses em conflito se manifestarão também no plano geral das ideias e, para o que nos toca aqui, na teoria econômica. A polêmica teórica e ideológica entre economistas permanecerá permeando o campo de conhecimento dessa disciplina chamada Economia ou Economia Política. Não há como imaginá-la neutra, destituída de juízos de valor, em que as distinções entre os seus praticantes sejam feitas apenas por preferência pelos instrumentos técnicos de análise empregados, ou pelo uso da "boa teoria". O que se buscou neste texto foi explicitar essa discussão e, por meio dela, colocar à disposição dos estudantes de Economia, e de outros estudiosos interessados, o conteúdo teórico daquilo que os economistas chamam de firma.

\section{Referências}

ALCHIAN, A. A.; DEMSETZ, H. (1972). Production, costs, and economic organization. In: BUCKLEY, Peter J.; MICHIE, Jonathan (Eds.). Firms, organizations and contracts: a reader in industrial organization. Oxford/New York: Oxford University Press, p. 75-102 1996.

ANKARLOO, D.; PALERMO, G. Anti-Williamson: a marxian critique of new institutional economics. Cambridge Journal of Economics, v. 28, p. 413-429, 2004.

AOKI, M. (1988). La estructura de la economía japonesa. México: Fondo de Cultura Económica, 1990.

BERLE, A. A.; MEANS, G. C. (1932). A moderna sociedade anônima e a propriedade privada. São Paulo: Abril Cultural, 1984.

BEST, M. H. (1990). The new competition: institutions of industrial restructuring. Cambridge, UK: Polity Press, 1993.

BLOCH, H.; FINCH, J. Firms and industries in evolutionary economics: 
lessons from Marshall, Young, Steindl and Penrose. Journal of Evolutionary Economy, v. 20, n. 139-162, 2010.

BRUE, S. L. (2000). História do pensamento econômico. São Paulo: Pioneira Thomson Learning, 2005.

CAZADERO, M. Las revoluciones industriales. México: Fondo de Cultura Económica, 1995.

CHANDLER,A.D. (1960). Desenvolvimento, diversificação e descentralização. In: MCCRAW, Thomas K. (Org.). Alfred Chandler: ensaios para uma teoria histórica da grande empresa. Rio de Janeiro: Editora da Fundação Getúlio Vargas, p. 67-118, 1998.

CHANDLER, A. D. (1967). A grande empresa industrial e a evolução da moderna economia norte-americana. In: MCCRAW, Thomas K. (Org.). Alfred Chandler: ensaios para uma teoria histórica da grande empresa. Rio de Janeiro: Editora da Fundação Getúlio Vargas, p. 170-196, 1998.

CHANDLER,A. D. (1990). A lógica duradoura do sucesso industrial. In: MONTGOMERY, Cynthia A.; PORTER, Michael E. (Orgs.). Estratégia: a busca da vantagem competitiva. Rio de Janeiro: Campus, p. 271-291, 1998.

CHANDLER,A. D. Organizational capabilities and the economic history of industrial enterprise. Journal of Economic Perspectives, v. 6, n. 3, p. 79-100, 1992.

CHANDLER, A. (1959). Os primórdios da "grande empresa" na indústria norte-americana. In: MCCRAW, Thomas K. (Org.). Alfred Chandler: ensaios para uma teoria histórica da grande empresa. Rio de Janeiro: Editora Fundação Getúlio Vargas, p. 35-66, 1998.

CHANDLER, A. D. Scale and scope: the dynamics of industrial capitalism. Cambridge, Massachusetts/London, England:The Belknap Press of Harvard University Press, 1990.

CHANDLER, A. D. The visible hand: the managerial revolution in american business. Cambridge, Massachusetts/London, England:The Belknap of Harvard University Press, 1977. 
COASE, R.H.(1937). The nature of the firm. In:BUCKLEY, Peter J.; MICHIE, Jonathan (Eds.). Firms, organizations and contracts: a reader in industrial organization. Oxford/New York: Oxford University Press, p. 40-58,1996.

GUIMARÃES, E. A. Acumulação e crescimento da firma: um estudo de organização industrial. Rio de Janeiro: Zahar Editores, 1982.

HALL, R. L.;HITCH, C.J. (1939). A teoria dos preços e o comportamento empresarial. In: Clássicos de literatura econômica. Rio de Janeiro: IPEA/INPES, 1988.

HAWKINS, C.J. Theory of the firm. Macmillan Studies in Economics.London/ Basingstoke:The Macmillan Press Ltd., 1973.

HENDERSON,W. O. (1969). A Revolução Industrial. São Paulo:Verbo/Editora da Universidade de São Paulo, 1979.

HODGSON, G. M. (1988). Economics and institutions: a manifesto for a modern institutional economics. Cambridge-UK: Polity Press, 1996.

JENSEN, M. C.; MECKLING, W. H. (1976). Theory of the firm: managerial behavior, agency costs, and ownership structure. In: BUCKLEY, Peter J.; MICHIE, Jonathan (Eds.). Firms, organizations and contracts: a reader in industrial organization. Oxford/New York: Oxford University Press, p. 103-167, 1996.

LAZONICK,W. Business Organization and the myth of the market economy. New York, USA: Cambridge University Press, 1991.

LAZONICK, W. Understanding innovative enterprise: toward the integration of economic theory and business history. In:AMATORI, Franco;JONES, Geoffrey (Eds.). Business History Around the World. New York, 2003.

LEE, F. S. Heterodox economics. The Long Term View, v. 7, n. 1, p. 23-30, 2008.

LEE, C. H. Corporate behaviour in theory and history: I. The evolution of theory. Business History, v. 32, n. 1, p. 17-31, 1990.

MARGLIN, S. (1974). Cuál es la función del jefe? Orígenes y funciones de la je- 
rarquía en la producción capitalista. In: PUTTERMAN, Louis (Ed.). La naturaleza económica de la empresa. Madrid: Alianza Editorial, 1994.

MARSHALL,A. (1920). Princípios de economia: tratado introdutório, v. I e II. São Paulo: Abril Cultural, 1982.

MARX, K.; ENGELS, F. (1848). Manifesto comunista. São Paulo: Boitempo, 2010.

MILGROM, P.; ROBERTS, J. Economics, organizations and management. Englewood Cliffs, New Jersey: Prentice-Hall, 1992.

NELSON, R. R. (1991). Por que as empresas diferem e qual é a importância disso? In: NELSON, Richard R. As fontes do crescimento econômico. Campinas: Editora da Unicamp, p. 165-194, 2006.

NELSON, R. R.;WINTER, S. G. (1982). Uma teoria evolucionária da mudança econômica. Campinas: Editora da Unicamp, 2005.

NONAKA, I.; TOYAMA, R.; NAGATA, A. A firm as a knowledge-creating entity: a new perspective on the theory of the firm. Industrial and Corporate Change, v. 9, n. 1, p. 1-20, 2000.

PENROSE, E. (1959). A teoria do crescimento da firma. Campinas, SP: Editora da Unicamp, 2006.

PORTER, M. E. (1985). Vantagem competitiva: criando e sustentando um desempenho superior. Rio de Janeiro: Campus, 1989.

RICHARDSON, G. B. The organization of industry. The Economic Journal, p. 883-896, 1972 .

ROBINSON, J. (1933). Economía de la competencia imperfecta. Barcelona: Ediciones Martinez Roca, 1973.

ROSENBERG, N.; BIRDZELL Jr., L. E. A história da riqueza do ocidente: a transformação econômica no mundo industrial. Rio de Janeiro: Editora Record, 1986. 
RUTHERFORD, M.What is wrong with new institutional economics (and what is still wrong with the old)? Review of Political Economy, v. 1, n. 3, p. 299318, 1989.

SCHUMPETER, J. A. (1942). Capitalismo, socialismo e democracia. Rio de Janeiro: Zahar Editores, 1984.

SCHUMPETER, J. A. (1954). História da análise econômica. Rio de Janeiro/ Lisboa: Editora Fundo de Cultura, 1964.

SIMON, H. A. Theories of decision-making in economics and behavioral science. American Economic Review, v. 49, n. 3, p. 253-283, 1959.

SIMON, Herbert A. Rational decision making in business organizations. American Economic Review, v. 69, n. 4, p. 493-513, 1979.

SMITH, A. (1776). Investigación sobre la naturaleza y causas de la riqueza de las naciones. México: Fondo de Cultura Económica, 1958.

SRAFFA, P. (1926). As leis dos rendimentos sob condições de concorrência. In: Clássicos de Literatura Econômica. Rio de Janeiro: IPEA/INPES, 1988.

TEECE, D. J.; PISANO, G.; SHUEN, A. Dynamic capabilities and strategic management. Strategic Management Journal, v. 18, n. 7, p. 509-533, 1997.

TIGRE, P. B. Inovação e teorias da firma em três paradigmas. Revista de Economia Contemporânea, n. 3, p. 67-111, 1998.

VARIAN, H. R. (1996). Microeconomia: princípios básicos. Rio de Janeiro: Campus, 1999.

WERNERFELT, B. A resource-based view of the firm. Strategic Management Journal, v. 5, p. 171-180, 1984.

WILLIAMSON, O. E. (1975). Mercados y jerarquías: su análisis y sus implicaciones antitrust. México: Fondo de Cultura Económica, 1991.

WILLIAMSON, O. E. Emergence of the visible hand: implications for industrial 
organization. In: CHANDLER, Jr.; ALFRED D.; DAEMS, Herman (Eds.). Managerial hierarchies: comparative perspectives on the rise of the modern industrial enterprise. Cambridge, Massachusetts/London, England, p. 182-202, 1980.

WILLIAMSON, O. E. (1985). Las instituciones económicas del capitalismo. México: Fondo de Cultura Económica, 1989.

WILLIAMSON, O. E. The modern corporation: origins, evolution, attributes. Journal of Economic Literature, v. 19, p. 1537-1568, 1981. 